\title{
PELUANG PENGEMBANGAN ECOPRENEURSHIP MENGGUNAKAN PERSPEKTIF KREATIFITAS LAYANAN
}

\author{
Muhammad Yasser Iqbal Daulay ${ }^{1}$. \\ Fachri Eka Saputra² \\ Sularsih Anggarawati ${ }^{3}$
}

Manajemen, Fakultas Ekonomi dan Bisnis, Universitas Bengkulu, Indonesia

\begin{abstract}
Abstrak
Ekowisata menawarkan bentuk perjalanan yang berbeda dari pariwisata massal. Ekowisata juga menyediakan proses pembelajaran untuk melindungi dan merawat alam, dan meningkatkan kesejahteraan masyarakat lokal di sekitar atau di dalam tujuan ekowisata. Studi ini dilakukan untuk menemukan pendekatan yang tepat untuk mengembangkan ekowisata. Fokus utama diberikan pada potensi ekowisata regional, termasuk sumber daya manusia, budaya, dan pendukung. Penelitian juga dilakukan untuk menentukan perspektif wisatawan karena memenuhi kebutuhan mereka tidak dapat dipisahkan dari tujuan bisnis. Penelitian ini menggunakan sumber data yang dikelompokkan menjadi dua, yaitu data primer dan sekunder. Data primer diperoleh melalui beberapa instrumen seperti survei, wawancara, dan observasi.
\end{abstract}

Kata Kunci: Inovasi Sosial, Pariwisata Ekologi, Inovasi Kewirausahaan

\begin{abstract}
Ecotourism offers a different form of travel than mass tourism. Ecotourism also provides a learning process to protect and care for nature, and improve the welfare of local communities around or within the ecotourism destination. This study was conducted to find the right approach to developing ecotourism. The main focus is given to the potential of regional ecotourism, including human, cultural, and supporting resources. Research is also conducted to determine the perspective of tourists because meeting their needs cannot be sustainably separated from business goals. This study uses data sources grouped into two, namely primary and secondary data. Primary data obtained through several instruments such as surveys, interviews, and observations.

Keywords: Social innovation; tourism; ecological tourism; entrepreneurial innovation
\end{abstract}

Article History: Received: (18-12-2019); Revised: (13-01-2020); and Published: (30-04-2020) Copyright @ 2020 M Yasser Iqbal Daulay, Fachri Eka Sautra, Sularsih Anggarawati

How to cite this article: Daulay, M.Y.I., Saputra, F.E., Anggarawati.S.(2020). Peluang Pengembangan Ecopreneurship Menggunakan Perspektif Kreatifitas Layanan. Managament Insight: Jurnal IImiah Manajemen. 15(1), 108-119 


\section{PENDAHULUAN}

Kewirausahaan ekologi merupakan suatu bisnis yang bukan hanya fokus pada keuntungan, akan tetapi juga memberikan manfaat positif terhadap kelestarian lingkungan alam. Kewirausahaan ekologi juga dikenal sebagai kewirausahaan lingkungan dan eko-kapitalisme. Dimana, pengusaha memanfatkan peluang ini untuk meningkatkan kualitas lingkungan dan juga memperoleh keuntungan.

Kewirausahaan Ekologi merupakan sesuatu yang baru dalam industri pariwisata di Indonesia, dimana para turis akan disajikan dengan pengalaman perjalanan wisata yang berbeda. Saat ini, pasar ekowisata mengalami pertumbuhan yang sangat signifikan. Faktor ini dipengaruhi oleh pola perilaku turis baik domestik ataupun mancanegara yang ingin menikmati lingkungan secara alami dan jauh dari polusi udara dan suara. Serta, kearifan lokal budaya masyarakat indonesia yang sangat beragam menjadi suatu keunikan yang tidak lepas dari faktor pendorong peningkatan ekowisata di Indonesia. Faktor-faktor ini secara langsung akan menimbulkan kerekatan interaksi antara turis dan masyarakat menjadi sangat kuat (Ghosh et al., 2003). Komunikasi yang tercipta baik secara verbal, maupun nonverbal antara turis dan masyarakat lokal akan menimbulkan dampak secara sosial dan ekonomi (Turco et al., 2003).

Dalam konteks ekowisata di Indonesia, Sebagian besar fasilitas wisata dikelola secara langsung oleh masyarakat sekitar. Fakta ini ditimbulkan oleh efek berganda dari kehadiran turis pada suatu lokasi wisata. Oosterman (1999) menjelaskan bahwa turis akan menghabiskan lebih banyak uang dan waktu selama perjalanan menuju objek ekowisata. Sehingga, pengembangan ekowisata akan menciptakan lapangan pekerjaan baru, dan tempat usaha baru seperti, tempat makan, restoran, toko cinderamata, transportasi, dan penginapan. Oleh karena itu, pengembangan ekowisata yang tepat akan meningkatkan kesejahteraan masyarakat dalam kawasan tujuan ekowisata. Selain itu, pengembangan ekowisata juga akan memastikan ketahanan lingkungan terutama untuk wilayah-wilayah konservatif.

Pariwisata Provinsi Bengkulu saat ini sedang menuju Visit Bengkulu 2020. Objek wisata berlatar ekowisata mulai tumbuh dibeberapa daerah seperti, Kabupaten Rejang lebong dan kota Bengkulu. Secara pengelolaan, ekowisata di Provinsi Bengkulu diinisiasi oleh penduduk lokal. Proses kreatifitas yang dibentuk mengacu pada hasil observasi pada kesuksesan daerah-daerah lain seperti, Bandung, Malang, dan Yogyakarta. Sebagai salah satu bentuk peningkatan layanan kepada pelanggan dan dapat meningkatkan minat wisatawan lokal, domestik, bahkan mancanegara.

Para peneliti telah memberikan penekanan besar pada potensi insentif yang dimiliki pengusaha berinvestasi dalam kewirausahaan hijau serta pengaruh nyata kewirausahaan ekologi tentang lingkungan alam (Dean dan McMullen, 2007; Hall et al., 2010). Berdasarkan masalah sebelumnya, beberapa literatur menyoroti peningkatan profitabilitas dan pengembangan peluang wirausaha baru (Kirkwood dan Walton, 2010). Dean dan McMullen (2007) meneliti berbagai peluang bagi pengusaha ekologi 
muncul dari kegagalan pasar seperti, eksternalitas negatif dan kondisi monopolistik. Albrecht (2002) menjelaskan bahwa peraturan pemerintah yang baik tentang perlindungan lingkungan akan memainkan peran penting dalam preferensi pengusaha untuk berinvestasi dalam kewirausahaan ekologi. Beragam orientasi ekonomi dan sosial mengungkapkan kesenjangan penelitian tentang kerangka kerja yang tepat dan berguna untuk mengidentifikasi faktor pendorong utama yang menjelaskan wirausahawan menjadi kewirausahaan ekologi (Kirkwood dan Walton, 2010; Meek et al., 2010)

Tujuan penelitian ini adalah mengeksplorasi pengembangan peluang kewirausahaan ekologi untuk studi kewirausahaan dengan menekankan pengembangan secara bertahap dan dengan menghasilkan sintesis ide konstruktif pada bidang kewirausahaan dan inovasi. Beberapa literatur kewirausahaan mengungkapkan bahwa terdapat proses penyerapan pengetahuan kreatifitas personal terhadap proses penciptaan produk yang kreatif atas kondisi yang kurang memadai. Penelitian ini mencoba mengisi celah tersebut melalui dua cara, yaitu bagaimana fitur potensial pada diri seorang wirausahawan dapat hadir dalam kondisi ketidakpastian, serta mampu bertindak dalam menghadapi kebutuhan akan produk yang kreatif.

Peluang kewirausahaan berkaitan dengan serangkaian wawasan memperkuat, memodifikasi, atau saling bertentangan muncul sebagai satu tindakan untuk menyelesaikan ketidakpastian. Di samping itu, penelitian ini menekankan bahwa pengaruh situasional dan lingkungan sosial mempengaruhi perilaku personal dalam memberikan informasi dan interpretasi baru, memperkuat keyakinan, dan pengetahuan pengusaha potensial tentang peluang inovasi yang berkembang saat ini.

\section{TINJAUAN PUSTAKA}

\section{Pengembangan Teori}

Kreativitas merupakan elemen kunci dalam proses pembentukan inovasi, dimana kewirausahaan sosial dan ekologi membutuhkan inovasi untuk memberikan solusi. Maka dari itu, penelitian ini akan berfokus pada teori pembentukan kreatifitas menggunakan kerangka 4P (process, people, press, dan product) (Dimov, 2007). Setiap komponen akan dibahas di bawah ini.

\section{Personal}

Personal mengacu pada karakteristik dan motivasi seseorang individu yang kreatif. Amabile (1998) menjelaskan tiga komponen keterampilan, yaitu berpikir kreatif, keahlian dan motivasi. Woodman et al. (1993) menambahkan bahwa komponen kepribadian menjadi salah satu komponen penting dalam pembentukan kreativitas seseorang. Komponen pembentukan kreatifitas tersebut mengacu pada 
faktor karakteristik individu. Sementara itu, faktor motivasi khususnya motivasi intrinsik menjadi pendorong yang sangat kuat bagi seorang individu untuk menggerakkan ide-ide kreatif dan menyelesaikan masalah yang dihadapi. Seorang pengusaha juga dapat dimotivasi secara ekstrinsik dengan adanya imbal hasil yang besar. Shepherd dan DeTienne (2005) menjelaskan bahwa seorang wirausahawan akan lebih inovativ pada saat peluang imbal hasil yang akan diperoleh menjadi lebih besar. Potensi imbal hasil secara keuangan menjadi salah satu motivasi ekstrinsik dalam pembentukan inovasi seorang individu.

Patzelt dan Stephard (2010) dalam penelitiannya menjelaskan bahwa terdapat motivasi tambahan dalam pembentukan inovasi, dimana para pengusaha ekologi mengaku termotivasi oleh ancaman kondisi ekosistem alam yang semakin buruk. Isaak (2002) memandang kewirausahaan ekologi memiliki persamaan dengan bisnis hijau. Faktor ini dapat dilihat dengan motivasi yang melatar belakangi pembentuknya. Hansesn et al. (2012) membantah bahwa bisnis hijau berbeda, dimana perusahaan atau wirausahawan mengembangkan suatu produk secara khusus untuk memecahkan masalah lingkungan. Oleh karena itu, menjadi motivasi utama dalam membangun bisnisnya. Selain itu, bisnis hijau merupakan refleksi atas keinginan pasar dan atau untuk memperoleh keunggulan kompetitif semata, dengan demikian lingkungan bukanlah motivasi utama dalam menjalankan bisnis.

\section{Tekanan}

Tekanan dapat menjadi faktor pendorong untuk meningkatkan kreativitas, dan pada sisi lainnya tekanan juga dapat menjadi pembatas bagi individu untuk mengeluarkan kreatifitas yang dimiliki (Woodman et al., 1993). Amabile (1998) mengidentifikasi pengaruh situasional yang positif dapat mengembangkan kreativitas individu pada level yang tidak terbatas. Pengaruh-pengaruh tersebut dapat dibentuk oleh adanya kebebasan, otonomi, sumber daya, dorongan, kebebasan dari kritik dan norma. Lebih dari itu, seorang individu menginginkan hasil dari inovasi dapat dihargai. Situasi ini lazim dalam kewirausahaan karena pengusaha mengendalikan atas dirinya sendiri dan mengembangkan lingkungan yang mereka inginkan dalam bisnis nya. Faktor negatif atas tekanan seperti, tekanan waktu, persaingan, jejaraing sosial, biaya, sumber daya, kurangnya otonomi, dan pendapat orang lain menjadi benang merah atas lemahnya motivasi dalam pembentukan kreatifitas. Dengan kata lain, faktor negatif motivasi eksternal memiliki pengaruh yang jauh kurang efektif apabila dibandingkan dengan faktor motivasi intrinsik (Hansen et al., 2012).

\section{Proses}

Proses kreatif merupakan hasil pemikiran dan tindakan yang diimplementasikan dalam produk yang bermanfaat (Lubart, 2001). Sudah ada berbagai model yang terdiri dari tiga elemen yang telah berkembang dari waktu ke waktu untuk 
memetakan proses kreatifitas. Ketiga proses kreatifitas tersebut akan dijelaskan berikut ini: 1). Persiapan penggunaan, 2). memperoleh pengetahuan, 3). keterampilan. Pengetahuan yang dimaksud adalah bersifat umum atau lebih khusus terkait dengan suatu masalah tertentu. Kreativitas seringkali merupakan hasil dari penerapan operasi mental dasar menuju struktur pengetahuan yang ada (Ward, 2004). Corbett (2005) mengemukakan bahwa persiapan melibatkan pembelajaran secara tidak langsung dengan ide bisnis tertentu, seperti bagaimana belajar cara menulis rencana bisnis atau pengetahuan umum tentang berbagai bentuk hukum bisnis. Lumpkin et al. (2004) menjelaskan bahwa wawasan merupakan momen realisasi di mana solusi potensial menjadi nyata atau baru sebatas kemungkinan yang dirasakan. Wawasan tidak hanya mengacu pada manifestasi besar, tetapi juga dapat mencakup koleksi bertahap atas wawasan- wawasan kecil.

\section{Produk}

Dimov (2007) mencatat bahwa salah satu manfaat dari menggunakan perspektif kreativitas dalam konteks alam adalah terciptanya peluang yang secara relevan akan menghasilkan produk kreatif. Komponen produk kreativitas berfokus pada hasil dari proses kreatif (Runco, 2004). Sebagai contoh dari hasil nyata pengembangan suatu produk kreatif didalam ilmu pengetahuan seperti konsep bisnis, model bisnis dan rencana bisnis (Ardichvili et al., 2003). Dalam penelitian ini, produkproduk kreatif adalah ide-ide baru, perluasan ide-ide yang ada, atau pergerakan ide yang telah ada ke arah baru.

\section{METODE PENELITIAN}

Metode yang digunakan dalam penelitian ini adalah deskriptif kualitatif. Keuntungan dangan menggunakan metode tersebut adalah penulis mendapatkan berbagai variabel yang berasal dari pelaku bisnis yang telah ada, dan pengalaman konsumen. Menurut Cooper dan Schindler (2014: 146), penelitian dengan menggunakan pendekatan kualitatif ditujukan untuk mendapatkan pemahaman tentang personality, motivasi, dan proses pembentukan kreatifitas oleh penyedia layanan ekowisata.

Penelitian kualitatif mempunyai kecenderungan dalam menggunakan ukuran sampel yang kecil karena tujuan dari riset adalah mendapatkan pemahaman selukbeluk tentang suatu hal secara mendalam (Cooper dan Schindler 2014: 147). Untuk mendapatkan pemahaman pada proses kreatifitas layanan, maka unit analisis dari penelitian ini adalah pengelola ekowisata, dan konsumen yang pernah berkunjung di wisata alam Provinsi Bengkulu.

Penelitian kualitatif tergambar dari bermacam-macam sumber data, yaitu berasal dari individu, perusahaan dan lingkungan bisnis yang ada (Cooper dan Schindler, 2014: 144). Penelitian ini mengguanakan sumber data yang dikelompokkan 
menjadi dua, yaitu data primer dan sekunder. Data primer diperoleh melalui beberapa instrumen seperti, survei, wawancara, dan observasi.

Peneliti melakukan wawancara individu secara mendalam kepada tiga pengelola ekowisata, yaitu Hutan Mangrove Bengkulu, Taman Bunga Rejang Lebong, dan Taman Bunga Beta Agro. Wawancara ini bertujuan untuk memperoleh gambaran tentang pemahaman pada proses kreatifitas layanan. Pencatatan data yang digunakan adalah dengan menggunakan lembar catatan wawancara dan ponsel pintar sebagai alat perekam langsung di lokasi wawancara.

Metode analisis data yang dilakukan pada penelitian ini adalah analisis deskriptif kualitatif. Analisis ini berfokus pada interpretasi konten dari pengisian kuesioner oleh responden dan hasil wawancara. Data yang diperoleh selanjutnya akan diinterpretasikan dan dijelaskan dalam bentuk narasi yang sesuai dengan data, serta fakta yang diperoleh dari lapangan.

\section{HASIL PENELITIAN}

Berdasarkan wawancara mendalam yang telah dilakukan pada tiga narasumber bisnis ekologi yang berada di Provinsi Bengkulu (lihat tabel 1), peneliti menemukan pola umum diantara pengusaha ekologi yang berbeda dalam empat variabel seperti: produk, personal, tekanan, dan proses. Pola tersebut dirangkum pada Tabel 2.

Tabel 1.

\begin{tabular}{cccc}
\hline \multicolumn{1}{c}{ Nama Usaha } & Lokasi & Isu Utama \\
\hline P1 & Hutan Mangrove & Kota Bengkulu & Taman Hutan Bakau \\
P2 & Taman Bunga Rejang Lebong & Kabupaten Rejang Lebong & Kelestarian Bunga \\
P3 & Taman Bunga Beta Agro & Kabupaten Rejang Lebong & Kelestarian Bunga
\end{tabular}

Sumber: Data Primer (2019) 
Tabel 2. Pola Umum Pembentukan Kreatifitas dalam Kewirausahaan Ekologi

\begin{tabular}{|c|c|c|}
\hline No. & Variabel & Hasil \\
\hline 1. & Produk & $\begin{array}{l}\text { - Wisata ekologi dibentuk untuk menjadi wadah masyarakat untuk mencintai alam } \\
\text { dan mempelajari peran penting alam untuk keberlangsungan hidup. } \\
\text { - Meningkatnya gaya hidup masyarakat untuk kembali ke alam, menjadi peluang } \\
\text { untuk pembentukan bisnis berbasis ekologi. }\end{array}$ \\
\hline 2. & Personal & $\begin{array}{l}\text { - Pembentukan kreatifitas berangkat dari pengetahuan dan keahlian dalam bidang } \\
\text { ekologi (faktor intrinsik) } \\
\text { - Harapan akan imbal hasil menjadi faktor pendukung yang memotivasi untuk } \\
\text { menciptakan usaha berbasis ekologi. }\end{array}$ \\
\hline 3. & Tekanan & $\begin{array}{l}\text { Motivasi dalam pembentukan kreatifitas berangkat dari kebebasan untuk menciptakan } \\
\text { lingkungan alam yang sehat } \& \text { indah, kebebasan dalam pengelolaan sumber daya, serta } \\
\text { dorongan kuat intrinsik untuk mengedukasi masyarakat akan pentingnya alam bagi } \\
\text { kehidupan. }\end{array}$ \\
\hline 4. & Proses & $\begin{array}{l}\text { Pengetahuan dan keterampilan merupakan faktor yang memotivasi untuk menciptakan } \\
\text { ide kreatif pembentukan bisnis berbasis ekologi. }\end{array}$ \\
\hline
\end{tabular}

Sumber: Data Primer (2019)

Secara umum, ide pembentukan usaha berbasis ekologi berangkat dari kesadaran untuk mengedukasi masyarakat akan peran penting lingkungan ekologi bagi keberlangsungan hidup manusia. Kehidupan perkotaan yang mulai mengeliminasi kesadaran masyarakat akan pentingnya kehidupan alam, merupakan motivasi utama untuk mendorong masyarakat mempelajari dan menghargai alam sebagai tempat tinggal utama manusia. Disamping itu, pola hidup masyarakat perkotaan yang semakin sadar akan lingkungan yang alami menjadi peluang untuk membentuk suatu bisnis yang berbasis ekologi di provinsi Bengkulu. Pembentukan produk kreatifitas juga berasal dari tren pasar yang ada pada generasi muda seperti, berfoto pada tempattempat wisata yang menarik. Faktor ini juga berangkat dari faktor eksternal, dimana preferensi informasi berasal dari keberhasilan yang berlangsung dari daerah lainnya.

P1: Lama-kelamaan masyarakat pada akhirnya akan kembali kealam, nantinya bisnis

ini pasti akan banyak dilirik oleh masyarakat.

P2: Kami juga melihat dari televisi dan internet yang sedang viral di daerah lain seperti, di Bandung dan Jogja...

P3: Sekarangkan banyak anak muda yang senang selfie-selfie di alam terbuka, ini lah

menjadi peluang usaha bagi kami untuk menyediakan tempat bagi mereka...

Kreatifitas layanan kewirausahaan ekologi dibentuk berdasarkan faktor personal pengusaha itu sendiri. Pengusaha memiliki preferensi personal yang berangkat dari pengetahuan dan keahlian pada bidang ekologi. Pengusaha memiliki

Daulay, Saputra, dan Anggarawati 
latar belakang khusus dalam bidang ekologi, sehingga pengusaha dapat mengembangkan kemampuannya untuk membentuk bisnis yang berbasis ekologi. Selain itu, minat dan hobi pengusaha menjadi indikator kuat dalam pembentukan kreatifitas layanan yang dapat ditawarkan secara menarik kepada konsumen. Sebagai imbal hasil dari kerja keras yang dilakukan oleh pengusaha, terdapat motivsi kuat untuk memperoleh hasil yang sesuai dalam bentuk penghargaan dan keuangan. Secara umum, faktor internal masih menjadi motivasi utama dalam pembentukan kreatifitas secara personal. Meskipun, motivasi eksternal sampai dengan saat ini belum dapat diperoleh secara maksimal oleh para pengusaha.

P2: Saya melakukan ini semua karena hobi bang!, jadi ingin hobi ini dapar tersalurkan dan bermanfaat buat orang banyak...

P1: ... karena basic saya dari pertanian jadi, saya mau tempat ini menjadi laboratorium Saya untuk mengaplikasikan ilmu pengetahuan yang Saya punya.

P3: ...cari uang lah bang, selama ini kita nelayan yang hasilnya terkadang ada kadang nggak ada, jadi layanan ini buat tambahan pemasukan kita aja kalau lagi nggak melaut.

Kreatifitas layanan yang dilakukan oleh pengusaha ekologi berangkat dari kebebasan

untuk mencipatakan lingkungan alam yang sehat dan indah, kebebasan dalam pengelolaan sumberdaya alam yang ada, serta untuk mengedukasi masyarakat akan peran penting alam bagi kehidupan. Kebebasan merupakan motivasi yang mendorong pengusaha untuk minciptakan kreatifitas layanan. Kekayaan alam yang dimiliki merupakan sumberdaya utama yang harus dilestarikan dan dideskripsikan kepada masyarakat. Kesadaran masyarakat untuk melestarikan alam yang mulai menurun, menjadi motivasi bagi pengusaha untuk menciptakan suatu bisnis yang dapat menumbuhkan kesadaran masyarakat akan arti pentingnya alam bagi keberlangsungan hidup manusia.

P1: Alam Indonesia itu sangat kaya, sangat sayang sekali kehidupan modern saat ini

mulai banyak melupakan alam sekitar. Contoh, hutan-hutan banyak ditebang untuk ditanami sawit, sawah-sawah ditimbun untuk dijadikan perumahan. Kita buat ini buat menyadarkan masyarakat kalau alam yang bersih itu sangat indah.

P2: Coba lihat tanaman ini indah sekali bukan? dengan cara ini kita mau kasih tau ke orang-orang kalau kita bisa menjaga alam dengan baik, alam juga akan kasih kita lebih.

P3: Sekitar sini banyak sekali hutan bakau, kita mau berbagi dengan masyarakat lain indahnya hutan bakau disini. 


\section{PEMBAHASAN}

Tujuan penelitian ini adalah untuk mengeksplorasi pengembangan peluang kewirausahaan ekologi yang ada di Provinsi Bengkulu. Kerangka kerja kreatifitas 4P telah digunakan untuk menganalisa temuan yang terdapat di lapangan. Diskusi tentang temuan-temuan penelitian dijelaskan berikut ini, diawali dengan bagaimana temuan yang dijelaskan diatas berhubungan dengan literatur yang ada tentang kewirausahaan ekologi, serta dikombinasi dengan kerangka kerja 4P.

\section{Kewirausahaan Ekologi}

Pilihan bisnis yang berfokus pada lingkungan menjelaskan konteks penelitian yang unik. Alasan utamanya adalah berhubungan dengan motivasi pengusaha dalam memilih wirausaha ekologi. Dalam kasus yang dijelaskan di atas terdapat perbedaan motivasi antara partisipan. P1 dan P2 menjadikan kepedulian terhadap lingkungan sebagai motivator utama untuk memulai bisnis. Fakta ini menunjukkan bahwa P1 dan P2 dapat dianggap sebagai kewirausahaan ekologi (Isaak, 2002). Para wirausahawan mengembangkan bisnis untuk memecahkan masalah lingkungan yang ditemukan, serta pemahaman tentang kondisi industri lokal yang ada. Kombinasi antara pengetahuan dan pengalaman tentang lingkungan dan persepsi ancaman alam merupakan anteseden untuk melihat peluang pembangunan yang berkelanjutan dan dimoderatori oleh pengetahuan wirausahawan (Patzelt dan Shepherd, 2010).

P3 lebih menekankan pada fakta bahwa bisnis ini adalah tren konsumen yang berkembang dan akan lebih bijaksana untuk melihat ini sebagai peluang. Namun, tidak berarti mereka tidak memiliki kepedulian terhadap lingkungan, akan tetapi lingkungan itu bukan motivator utama dalam membangun bisnis ekologi. Dengan demikian, P3 dapat dianggap sebagai bisnis hijau, dimana bisnis merupakan respons terhadap tren pasar. Sementara itu, lingkungan bukan merupakan motivator utama.

Perbedaan motivasi untuk memulai bisnis sedikit kurang jelas. Di sini, P1 dan P2 memiliki banyak kesamaan dari pada P3, mirip dengan motivasi lingkungan yang dibahas pada bagian sebelumnya. P3 menjadi seperti yang dijelaskan oleh Bhave (1994) dirangsang secara internal, mereka memutuskan memulai bisnis setelah melihat kebutuhan yang tidak terpenuhi di pasar. P1 dan P2 menjadi seperti yang dijelaskan oleh Bhave (1994) dirangsang secara eksternal, yaitu, mereka pertama kali memutuskan mereka ingin memulai bisnis dan kemudian mencari kebutuhan pasar yang selaras dengan pengetahuan, pengalaman dan keterampilan. Perbedaan ini menjadi keragaman dalam kegiatan pembentukan kreatifitas. 


\section{Produk dan Tekanan}

Produk utama dalam kasus ini adalah proses pengembangan ide bisnis. Seperti dijelaskan di atas, setiap kasus menunjukkan beberapa perubahan ide. Ketiga narasumber memiliki beberapa ide baru, akan tetapi untuk P3 dan P1 serta P2 gagasan dipicu oleh tekanan negatif. Bagi $\mathrm{P} 1$, tekanan yang muncul lebih berat sehingga ia harus menyusun bisnis yang sama sekali baru. Bagi P2 dan P3, tekanan yang muncul lebih bersifat laten dan karenanya mereka memikirkan tambahan produk lain yang mendukung konsep bisnis utamanya. Sebagai respon dari tekanan negatif yang diterimanya, P1 tidak terpengaruh untuk melakukan perubahan ide secara drastis. Fillis (2000) menjelaskan bahwa tidak jarang orang kreatif akan mengabaikan tekanan negatif.

\section{Kesimpulan}

Kreativitas adalah faktor kunci keberhasilan dalam perusahaan kecil dan kewirausahaan (Fillis, 2000). Kerangka kerja kreativitas 4P adalah kerangka yang berguna untuk memeriksa kreativitas yang melekat (Dimov, 2007a; Hansen dan Hills, 2004) dalam pengembangan peluang. Secara khusus, kreatifitas penting untuk mempertimbangkan interaksi 4Ps, terutama tekanan atau situasi (Dimov, 2007). Penelitian ini memberikan wawasan unik tentang pengembangan peluang di antara para ecopreneur. Dengan demikian, penelitian ini berkontribusi pada literatur yang berkembang menggunakan peluang perspektif pengembangan, bukan perspektif pengakuan atau penemuan. Penelitian ini juga berkontribusi pada literatur dengan memanfaatkan metode dari penelitian kreativitas, dengan demikian memperkuat hubungan yang diakui antara kreativitas dan kewirausahaan (Brazeal dan Herbert, 1999; Dimov, 2007a). Oleh karena itu, penelitian ini berkontribusi pada perkembangan literatur tentang kewirausahaan berkelanjutan (ecopreneurship).

Terbatasnya jumlah responden dalam penelitian ini bukan berarti tidak dapat menangkap secara keseluruhan aspek pola usaha sosial skala kecil dan menengah untuk tujuan generalisasi. Penelitian selanjutnya dapat mengksplorasi lebih banyaj kebutuhan perusahaan sosial dari sudut pandang yang berbeda, sehingga akan menghasilkan data yang lebih komprehensif. Perusahaan ecopreneurship dan sosial yang beragam dapat menjadi pertimbangan selanjutnya. Selain itu, mengeksplorasi tantangan dan solusi bisnis dengan melakukan survei dengan para pemangku kepentingan. 


\section{Daftar Pustaka}

Anderson, A.R. (1998). Cultivating the garden of eden: environmental entrepreneuring, Journal of Organizational Change Management, Vol. 11 No. 2, pp. 135-44.

Ardichvili, A., Cardozo, R., \& Ray, S. (2003). A theory of entrepreneurial opportunity identification and development. Journal of Business venturing, 18(1), 105-123.

Bansal, P. and Roth, K. (2000). Why companies go green: a model of ecological responsiveness, Academy of Management Journal, Vol. 43 No. 4, pp. 717-36.

Clemens, B. (2006). Economic incentives and small firms: does it pay to be green?, Journal of Business Research, Vol. 59 No. 4, pp. 492-500.

Cohen, B. and Winn, M. (2007). Market imperfections, opportunity and sustainable entrepreneurship, Journal of Business Venturing, Vol. 22 No. 1, pp. 29-49.

Cooper, D.R. and Schindler, P.S. (2014). Business Research Methods. New York: McGraw-Hill.

Corbett, A. C. (2005). Experiential learning within the process of opportunity identification and exploitation. Entrepreneurship Theory and Practice, 29(4), 473-491.

de Bruin, A. and Lewis, K. (2005). Green Entrepreneurship in New Zealand: A MicroEnterprise Focus, Ashgate Publishing, Aldershot.

Dimov, D. (2007). Beyond the single-person, single-insight attribution in understanding entrepreneurial opportunities. Entrepreneurship Theory and Practice, 31(5), 713-731.

Freimann, J., Marxen, S. and Schick, H. (2005). Sustainability in the Start-Up Process, Ashgate Publishing, Aldershot.

Ghosh, T. (2011). Coastal tourism: Opportunity and sustainability. Journal of Sustainable Development, 4(6), 67.

Keogh, P. and Polonsky, M. (1998). Environmental commitment: a basis for environmental entrepreneurship?, Journal of Organizational Change Management, Vol. 11 No. 1, pp. 38-49.

Laroche, M., Bergeron, J. and Barbaro-Folero, G. (2001). Targeting consumers who are willing to pay more for environmentally friendly products, The Journal of Consumer Marketing, Vol. 18 No. 6, pp. 503-20. 
Pastakia, A. (1998). Grassroots ecopreneurs: change agents for a sustainable society, Journal of Organizational Change Management, Vol. 11 No. 2, pp. 157-73.

Turco, D. M., Swart, K., Bob, U., \& Moodley, V. (2003). Socio-economic impacts of sport tourism in the Durban Unicity, South Africa. Journal of Sport Tourism, 8(4), 223239.

Schaltegger, S., Lüdeke-Freund, F., \& Hansen, E. G. (2012). Business cases for sustainability: the role of business model innovation for corporate sustainability. International Journal of Innovation and Sustainable Development, 6(2), 95-119.

Schaper, M. (2002a), "The essence of ecopreneurship", Greener Management International, Vol. 38, Summer, pp. 26-30.

Shepherd, D. A., \& DeTienne, D. R. (2005). Prior knowledge, potential financial reward, and opportunity identification. Entrepreneurship theory and practice, 29(1), 91112.

Shepherd, D. A., Patzelt, H., \& Haynie, J. M. (2010). Entrepreneurial spirals: Deviationamplifying loops of an entrepreneurial mindset and organizational culture. Entrepreneurship theory and practice, 34(1), 59-82.

Webb, D.J., Mohr, L.A. and Harris, K.E. (2008), A re-examination of socially responsible consumption and its measurement, Journal of Business Research, Vol. 61 No. 2, pp. 91-8. 